\title{
Reklamcılıkta Distopya Gerçeği: Reklamlara Yönelik Bir Analiz
}

\author{
Cihan BECAN ${ }^{1}$
}

Öz

Yaşadığımız tüketim çağında insanlar, geçmişe nazaran nasıl daha mutlu bir yaşama erişebileceğinin arayışı içerisinde olmuştur. Çoğu zaman tüketicilerine mükemmel bir dünya tasarımı vadeden reklamlar, her zaman onlara kendilerini özel hissettirerek ulaşmayabilir. Reklamın kusursuz dünyasına meydan okuyan distopik (anti-ütopik) söylem ile hazırlanmış reklamlar, korkudan ve tehditten yararlanarak hedef kitleyi satın almaya yönlendirebilir. Konunun kuramsal çerçevesinin 'distopya' kavramı ışığında ele alınması da böylesi bir gereksinimden ortaya çıkmıştır. Temel itibariyle bu çalışmada tüketim sistemiyle bağlantılandırılan distopya olgusunun ve distopik unsurların, sembolik tüketim mekanizmasının ana çarklarından biri olarak kabul edilen reklamlarda nasıl işlendiği gösterilmeye çalışılmaktadır. Bu çerçevede "Reklamda Distopik Çerçeve" nin ortaya koyduğu distopik bileşenler açıklanmış ve ülkemizde yayınlanan TV reklam spotları incelenmiştir. Televizyon ortamında yayınlanan reklamlara yönelik nitel araştırma yöntemi altında, metin analizi benimsenmiştir. Elde edilen verilere göre, reklamcılıktaki distopik çerçeveyi oluşturan unsurların televizyon reklamlarında görsel ve dilsel iletilerinde görüldüğü ve tüketimi pekiştirmek için kullanıldığı doğrulanmıştır.

Anahtar Kelimeler: Distopya, distopik çerçeve, reklam, tüketim, metin analizi.

Atıf: Becan, C. (2019). Reklamcılıkta Distopya Gerçeği: Reklamlara Yönelik Bir Analiz. Akdeniz Üniversitesi İletișim Fakültesi Dergisi, Haziran (31), s. 147-170

1 Dr. Öğretim Üyesi, İstanbul Aydın Üniversitesi İletişim Fakültesi, Halkla İlişkiler ve Tanıtım Bölümü, cihanbecan@aydin.edu.tr, ORCID: 0000-0002-1289-1360. 


\title{
The Dystopian Reality in the Field of Advertising: An Analysis on Commercials
}

\begin{abstract}
In the age of consumption we live, people have been in search of how they will have a happier life compared to the past. The commercials which mostly promise its target audience a perfect world design, may not always reach them by making them feel special. The dystopian (anti-utopian) literature that challenge the excellence world of commercial, by taking advantage of fear appeal, can direct people to buy any good and/ or service. The theoretical framework of the study focuses on the 'dystopia' because of such a social reality. This study mainly indicates how the concept of dystopia, which is linked to consumption system and dystopic elements, has operated on commercials as a symbolic consumption tool. The dystopic constituents in the "Dystopia in Advertising Framework" have been explained and analyzed with some samples of TV commercials. As a part of the research, textual analysis has been utilised under the qualitative research method. In conclusion, it has been proved that constituents in the Dystopia in Advertising Framework have been seen in the visual and linguistic messages of commercials and they have been used to reinforce the consumption.
\end{abstract}

Keywords: Dystopia, dystopic framework, advertising, consumption, textual analysis

\section{Giriș}

$\mathrm{R}$ eklamların, hayatımızın içine nüfuz eden ve toplumsal hayatımızı şekillendiren etkili bir kitle iletişim aracı olmakla beraber kültürel bir olgu haline geldiği görülmektedir. Küreselleşme akımının da etkisiyle ortaya çıkan metropol yaşantısı, aşırı bireysellik ortamını yaratmakta ve bireyin bu ortamda kendini kanıtlaması amacıyla bir farklılık sergilemesini gündeme getirmektedir. Tercihlerin artması, ekonomik gelirin gittikçe yükselmesi bireyleri, kimlik arayışına yönelterek tüketim kavramını ön plana çıkarmaktadır.

Tüketim, kimliği şekillendirmede önemli bir gerçeklik iken egemen kılınmış imgelerden oluşan reklamlar da doğrudan tüketim ortamını yaratmaktadır. Buradan hareketle, toplum içinde mevcut olan nesneleri böylece şekillendirme yoluna giden reklam iletileri, hiçbir yaşanmış gerçekliğe dayanmayan bir imajlar bütünü olarak sunulmaktadır. Bu açıdan gerçeğe değil, mutlak özgürlüğe ve kısıtlanmış mutluluğa götüren düşlere dayanmaktadır (Becan, 2015, s. 110).

Reklamlar aslında bireyleri, kendilerine gelen bilgileri yine kendi iradelerine göre yorumlamaktan alıkoyarak kapitalist sistemin içine dâhil etmeye çalışmaktadır. Diğer bir ifade ile tüketicinin gerçeklik duygusunu yaşayamadığı, edindiği bilgileri sorgulayamadığı dışarıya kapalı bir ortamda hareket etme esnekliğinden mahrum 
bırakmaktadır. Çalışma kapsamında distopya kavramının ele alınışı da bu sistemi oluşturan karakteristik özelliklerin aynı şekilde distopik evrende de karşılaşılmasıdır. Ortak nokta olarak "daha iyiye ve güzele ulaşmalısın" temasını aşıladığı reklam iletilerinin sürekli olarak insanları varlık içindeyken hiçliğe inandırması, yeterliyken yetersiz hissettirmesi, tükettikçe tüketime aç hale getirmesi gibi korkuları beslemesi söz konusudur (Becan, 2015, s. 151).

Toplumsal bir varlık olarak insanın başkaları tarafından kabul edilme ve onaylanma intiyacını sürekli hissetmesi bu korkuyu besleyen temel faktördür. Aslında temel mesele toplumun geri kalan kesimi tarafından beğenilmenin ve dışlanmamanın, ürünlerden geçerek karşılanmaya çalışılması konusudur. İnsanların bu tür zaaflarını kullanarak tasarlanan reklamlar, hedef kitleye kaygı, korku ve endişe yaratarak ulaşmaya çalışmaktadır. Bu makalede öncelikle distopya kavramı ve kapsamına ilişkin bir literatür araştırması yapıımış ardından kavramın reklam alanındaki yeri genel olarak incelenmiştir. Amaç reklamlarda yer verilen düşünce kalıplarının ve söylemin arka planında distopik gerçeklerin yattığını ifade etmek ve göstermek olduğundan, distopya kaynaklarıyla ortaya konulan Reklamcılıkta Distopik Çerçeve odağında televizyon reklamları analiz edilmiştir.

\section{Kavramsal Olarak Distopya ve Distopyanın Genel Kapsamı}

Ütopyalar her zaman mükemmel ve ideal bir düzeni elde etmek için insanoğlu tarafından hep incelenen bir konu olmuştur. Sosyal bilimler alanında politikada, felsefede, sosyolojide bir şekilde kendine yer bulan ütopyalar, var olan toplumsal yapıları sürekli etkilemeye çalışmıştır. İnsanlık tarihi var olduğundan bu yana her zaman geleceğe dair umutla bakmanın, kusursuz bir hayata kavuşmayı istemenin altında edebi anlamda ütopyalar vardır.

Ütopyalar tür itibariyle, doğru ve mutlu bir toplum düzenini anlatmaya çalışarak gelecekte daha iyi nasıl olması gerektiğini anlatmasına rağmen, yazıldıkları dönemin en temel sorunlarını ve kaygılarını açığa vurmaktadır. Diğer bir deyişle, her hangi bir ütopik düşünceyi bize iletmeye çalışan metinlerde aslında mutsuzluğun yaşandığı, sorunlu bir toplumu yansıttığı söylenebilir. Böyle bir fotoğraf ortaya koyan ütopik metinler, zaman içerisinde, tam karşı mecrada yerini almış ve distopya adı verilen başka bir biçime dönüşmüştür. (Becan, 2015, s. 26).

Ütopyaların yerini zamanla anti ütopyaya veya distopyalara bırakmasına temel sebep olarak ütopyaların kendi içinde başka bir alternatife şans tanımamasını göstermekle birlikte, bireysel eğilimlere yer verilmemesinin önemli bir etkisi olduğu belirtilmektedir (Öztürk, 2006). Buradan da anlaşılmaktadır ki ütopyalar, mevcut duruma yönelik alternatif bir seçenek iken kendi içerisinde başka bir yaşam durumuna veya seçeneğe yer vermemektedir. Bezel (1984, s. 9), ütopya ve distopyaların ortak yanı olarak tek bir anlayışın benimsenmesi ve bu doğrultuda hiçbir düşünce, duygu ve hayat tarzında farklılıkların kabul edilmemesinin altını çizmektedir. 
"Distopya" kavramının kaynaklara göre, 1747 yılında kimliği belirsiz olarak basılan ve Lewis Henry Younge için atfedilen Utopia: or Apollo's Golden Days adlı eserde doğrudan Utopia'nın karşıtı olarak açık bir şekilde kullanıldığı belirtilmektedir. Hayat koşullarının kötü olduğu ve her türlü olumsuzlukların yaşandığı bir topluma işaret eden, 'kakotopya' (cacotopia) terimini kapsayan distopya kavramı, 1818 yılında ilk defa Faydacılık kuramının öncüsü Jeremy Bentham tarafından ortaya atılmıştır (Budakov, 2010, s. 86). Distopya, Yunanca "dus" = 'zor' ve "topos" = 'yer' sözcüklerinden türetilen bir terim olarak karşımıza çıkmaktadır. Ütopya'nın olumsuzluk anlamı veren 'u' öneki ile 'topos' sözcüğünden üretilen "olmayan yer"i ifade ettiği gibi distopya ise "zorlu yer" i anlatır(Riot-Sarcey vd., 2003, s. 148).

Kumar'a(2006, s.172) göre distopya, malzemesini ütopyadan temin etmekte ve onu ütopyanın olumlanmasına karşı çıkan bir şekilde yeniden kurmaktadır. Dolayısıyla bu noktada, distopyanın süregelen bir biçimde ütopyanın arkasından geldiği anlaşılmaktadır. Diğer taraftan Jameson(2009, s.270) distopyayı ütopyanın kötü kardeşi olarak nitelerken, bunun etkilerinin bireyin sosyal olanaklarının olumlu bir şekilde kavranışı ışığında ortaya çıktığını ve siyasi açıdan ütopik ideallerden türediğini belirtmektedir. Vural ve Bakır (2007, s.12) ise distopyayı "içinde bulunulan zamanın olumsuz, istenmeyen koşullarının doğuracağı etkilerinden yola çıkarak bunların geleceğin dünyasındaki olumsuz yansımalarını çoğunlukla toplumsal bir kurgu düzeyinde ele alan öngörüsel tasarımlar" olarak ele almaktadır. Feenberg (1995, s.43)'e göre distopya kavramı, kaçışın imkânsızlığını ima ederken, toplumsal eleştirinin modern bilim ve teknoloji karşısında yok oluşunu ortaya koymaktadır. Darvish ve Najjar(2011, s.101) distopyayı tanımlarken, insanoğlunun ve toplumun geleceği için olumsuz bir tablo ortaya koyan, ütopya fikrine ve olasılığına karşı çıkan bir düzenden bahsetmektedir.

Literatürde yapılan bu tanımlar çerçevesinde genel itibariyle distopya kavramının ütopyanın karşıtı olarak değil, o düzenin resmettiği mükemmel, mutlu ve ideal tasarımların tersi olan baskıcı, tehditkâr ve totaliter düzenleri işaret etmek için kullanıldığını söylemek gerekmektedir. Yine yapılan tanımlar bize distopyanın temel kaynağının korku ve endişeye dayandığını göstermektedir. Dolayısıyla distopya, sosyopolitik ve sosyo-psikolojik ilişkilerin öne çıkartıldığı, kusursuzluğa yakın örgütlenmiş, gelecekteki totaliter toplumsal düzeni resmetmektedir. Söz konusu bu düzen, bireyin özgürlüğünün tamamen elinden alındığı karamsar ve tehdit edici bir yapı çizerken, korku dolu gelecek öngörüleriyle gelecekte yaşanabilecek olumsuzluklara karşı uyarmaktadır.

Distopik yaklaşımı tarihsel süreç içerisinde ele aldığımızda, bilim ve teknik alanında gelişme gösteren fakat umudu ve hayali elinden alınan bir toplum yapısına doğru geçiş gözlemlenmektedir. Güvenini ve inancını kaybeden insanoğlunu çizen bir gelecek tasarımı, ütopik düşüncenin düşüşe geçmesine paralel olarak distopyanın kendisini ortaya çıkardığına işaret etmektedir. Bu dönemde üretilen eserler de bu tablonun somut ve çarpıcı örnekleri olarak gösterilmektedir. Diğer bir açıdan bakacak olursak, bir tür mükemmel dünya vaad eden ütopyalar, sundukları "sorunsuz" ve "çatışmasız" sosyal 
düzenle gerçekliğin dışına kayarken, her hangi bir eleştirinin veya fikir çatışmasının olmamasını doğal kılmaktadır. (Becan, 2015, s. 52).

\section{Reklamcılık ve Distopya Illișkisi}

Distopik metinlerde ifade edilen soma ve benzer uyuşturucu maddeler, marşlar, ayin havasındaki toplantılar ve diğer benzer dikkat dağıtma araçları bireylerin birtakım korkulardan, düşüncelerden ve/veya duygulardan arınmalarını sağlayan ortamlar sunmaktadır. Günümüzde ise bu ritüelleri gerçekleştiren ve insanları başka bir noktaya odaklanmalarına etki ederek bir tür psikolojik rahatlama getiren aktörlerin başında medya gelmektedir. Kitle iletişim araçlarının önemli parçalarından reklamlar, diziler ve diğer sanal dünyalar, artık insanları ortak ayin gerçekleştirmeye çağırmak ve mevcut sistemi sürdürmek adına ikna aracı olarak kullanılmaktadır.

Dolayısıyla distopyalar, bireyler üzerinde gerçekleştirmek istediği yaşam tarzını kurduğu baskı ile üretmeye çalışmaktadır. Bu baskıyı siyasal ve toplumsal alanda gerçekleştirdiği gibi ekonomik yapı üzerinde de sürdürmektedir. Nasıl insanları düşüncelerinden ve sıkıntılarından arındırmak için soma ilacı veriliyorsa bugünün medyası ve medyanın önemli bir öğesi olan reklam da ekonomik istikrara katkı sağlamaktadır. İşte bu noktada, insanlar reklam aracılığıyla ürünü tükettiği ölçüde mükemmelliğe ulaşırken, düzenin sürekliliğine yardımcı olmaktadır. "Kapitalizm”in beslediği bu ortamda reklam, sunduğu öğeyle/ürünle sistemdeki, yapıdaki eksikliği tamamlamaktadır. Bu tamamlama ayrıca bir haz sunmaktadır. Birey, ürünü tükettiği sürece düzenin bir parçası haline gelirken, kendini sisteme ait hissettiğini zannetmektedir. Zaten distopyada da insanlar kurallara uyduğu sürece düzenin bir parçası olmaya devam etmektedir.

Özellikle popüler kültürden beslenen tüketim kültürü, egemen güçler tarafından yönlendirilen pazar mekanizmaları ve kültür endüstrileri aracılığıyla, güçlü sermaye sisteminin ve egemen düzenin yeniden üretilerek meşrulaştırılmasına destek sağlamaktadır. Tüketimin toplumsal yeniden üretimini sağlamak adına belirli mesajları kitle iletişim araçlarıyla (Internet, sosyal medya dahil) ileten reklamlar, pazar mekanizmalarının sermaye güçlerinin istediği şekilde çalışmasına hizmet etmektedir. Özellikle insanların kendi gerçek gereksinimlerinden ayrılıp sahte gereksinimlere gitmesinde, kendilerinden istenen şekilde tüketmesinde ve bu tüketimden zevk almalarının sağlanmasında en büyük rol sahibi reklamların ta kendisidir. Dolayısıyla medyanın lokomotif aracı konumundaki reklamlarda tekrar tekrar verilen tüketim mesajlarıyla tüketim ideolojisine yönelik belirli yaşam özentileri sunulurken, bireylere, gündelik hayatlarındaki kimlikleri ve davranış biçimleriyle hayat felsefeleri satılmaktadır. Sonuçta gündelik hayat artık bireyleri tüketime yönlendirmektedir (Meral, 2008: 186). Reklamları baskıcı bir unsur olarak kullanan egemen güçler, özgürlüğü güçlü bir egemenlik aracına çevirebilmektedir. Bireyler tamamen yanlış gereksinimlerle şartlandırılarak, çok çeşitli ürün ve hizmetler arasında bile toplumsal denetim altına girmekte ve kendisine yabancılaşmaktadır (Marcuse, 1970).

Wernick (1996, s. 7) reklamcılık ve onunla ilişkili diğer bütün uygulamaların, kültürel 
alanın her tarafına saçılmış olan bir retorik biçimi olarak baktığını, sahip olduğu niteliğiyle sadece kültürün "sembolik ve ideolojik içeriğini değil, aynı zamanda onun ethosunu, dokusunu ve bütünsel yapısını da" şekillendirdiğini söylemektedir. Kellner (2001, s. 214), reklamların belirli bir ürünün satın alınmasıyla ütopik, yeni, çok çekici, çok saygın ve çok farklı bir 'ben' imajı üreterek, tüketim davranışında ve tarzında sihirli bir biçimde yeni bir kimlik sunduğunu belirtmektedir. Bu şekilde reklam, tüketim talebini yönlendirici olduğu kadar toplumsallaşma aracı işlevini de üstlenmektedir. Berger (2007, s. 131), tüketimin lokomotifi konumundaki reklamların bireylere ürünler/ hizmetler/nesneler arasında seçme özgürlüğü sunduğunu, reklamların her zaman bireylere bir nesne daha satın aldırarak kendisini veya yaşam tarzını değiştirmeyi önerdiğini söylemektedir. Fakat reklamlar yoluyla alınan nesnelerin bireyi maddi ve/ veya manevi zenginleştirmenin aksine, o nesneyi aldıkça sürekli harcadığından daha da yoksullaştırdığını belirtmektedir.

Reklamlar, tüketicilere ideal benliklerini ve geleceğini oluşturmaya intiyaç duydukları sembolik kaynakları önermekte fakat hiçbir zaman uzun dönemli memnuniyet sağlamamaktadır (Shankar ve Fitchett, 2002, s. 503). Bugünün reklamcılığı bugünün toplumuna kendini daha rahat göstermek için inatçı bir şekilde kalıcı memnuniyetlerin aksine geçici arzular aşılamaktadır. Bu geçici arzuları aşılarken, tüketicilerin kendilerini mutlu ve tatmin eden öyküler örmektedir. Reklamlar, çeşitli anlamlarla bezenmiş bu öykülerle, - toplum tarafından güvenilir bir kişinin imajını kullanarak, çekici bir kadının cinselliğini ön plana çıkararak ya da kullandıktan sonra kendisini diğerlerinden ayrıcalıklı kılacak bir nesneyle - önce duygusal olarak etkilemekte, sonra itaat etmesini sağlamaktadır.

Reklamların temelinde yatan husus tüketicileri sürekli olarak gündelik pratikleri içerisinde huzursuz ederek, kendisini yetersiz görmesini sağlayarak ve hoşnutsuzluk aşılayarak çıtayı daha yukarıya çekme konusunda tetiklemesidir. Bu noktadan hareketle reklamcılığı insanlığın fantastik inkârı olarak nitelendiren Wilkinson, geçici mutlulukların, teknolojiye olan bağııı̆ın ve dildeki yozlaşmanın gittikçe arttığı distopik ortamda, diyet yaparak güzelleşme, daha geniş ev ve arabaya ulaşma, özellikli ürünlerle donatılmış yaşam tarzına sahip olma arzusunu taşıyan 'tüketici sınıf'ın geçmiş zamana nazaran daha yoğun kaygı ve depresyon yaşadığını ifade etmektedir (Wilkinson, 2010, s. 22).

Reklamların aslında insanların tüketirken tüketmeyi daha fazla kamçılaması ve kendilerini yetersiz göstermesi, başı başına distopik ideolojiyi beslediğini göstermektedir. Reklamlarda iletilen mesajlarda sürekli olarak bireyler üzerinde daha iyisine, mükemmeliyete ulaşana kadar hayat tarzlarını değiştirmeye yönelik bir baskı oluşturulmaktadır. Bu baskıyı yaşayan insanlar kusursuzluğa ulaşma idealinde hayatını sürerken, totaliter bir sistemin getirdiği tek tipleştirmenin kölesi olduğunun farkında olmamaktadır. Bu köleliğe iten itki tamamen insanların istediği yaşam tarzını sürememe, güzel ve çekici görünmeme, hayal ettiği nesneyi elde edememe, ayrıcalıklı olamama korkusudur. 


\section{Reklamcılıkta Distopik Çerçeve}

Buraya kadar bahsedilen teorik altyapı doğrultusunda, kitle iletişim araçlarından çıkan reklamlardaki distopik mesajların özelliklerini daha iyi anlamak üzere, daha bütüncül bir perspektiften incelenmesini olanak sağlayan bir çerçeve oluşturulmuştur. Bu bilgiler ışığında çerçeve, distopyadaki toplumsal gerçekliği ortaya koyan ve distopik ideolojiyi yansıtan 6 temel bileşenden oluşmaktadır.

\subsection{Korku}

Bir duygusal bileşen olarak korku, insanoğlunun hayatındaki varlığını sürekli korumakta ve hiçbir zaman gücünü yitirmemektedir. Sosyal hayatın birçok kesişim noktasında korku duygusundan beslenen bireysel ilişkileri gözlemlemek mümkündür. Korku duygusu, bireylerin düşünce alanını ve pek çok davranışını şekillendirirken, bu duygu durumunun özellikle insanların içinde yer aldığı ilişkilere, dünya görüşlerine, hayat tarzlarına, ürettiği sistemlere yansıması söz konusudur.

Distopik düşünceyi güçlü kılan ana temaların başında geleceğin bilinmezliği gelmektedir. Geleceğe yönelik bilinemeyene karşı duyulan çaresizlik, savunma mekanizması olarak bireyde korkunun ve tehdidin derecesini de yükseltmektedir. Geleceğe umutla bakan, seven, düşünen, eleştiren, kendini en iyi şekilde anlatabilen bireyler, çizilen baskıcı ve otoriter yapının getirdiği düzende söz konusu özelliklerini kaybederek kendi özünden korkan ve tehdit altında kaldığını hisseden insan tipine dönüşmektedir. Totaliter düzenin bir diğer temel amacı insanlara sürekli gözetim altında izlendiği hissini vermektir. Distopyada özgürlüğün yerini istikrar kavramı aldığı için istikrarı meşru kılmak adına çoğu zaman bir tehdit ortamı oluşturulmaktadır. Gözetimle çevrelenen insanların ifade özgürlükleri teknoloji ile artmasına rağmen, aynı teknolojideki gözetim, insanların düşüncelerini gizlemesine sebep olmaktadır. Bunun temelinde de bireysel özgürlüklerin artmasıyla birlikte devletlerin, bireylerin aynı oranda özel hayatına müdahale arzularının çatışması yatmaktadır (Sucu, 2011, s. 132).

Dolayısıyla mükemmel ve yıkılmaz sistemler adına, korku içerikli distopyaların, insanoğlunun ideal ve mutlu bir düzen oluşturma arzusunun ve gayretlerinin istenilen sonuca varamayacağı ve karamsar gelecek tasarımına taşıyacağı iddiasındadır. Teknolojik gelişmeler altında mekanikleşmenin artmasıyla beraber, her türlü değerlerin, duyguların ve inançların tahrip edilmesi, sistemin koşullandırılmış bir öğesi konumuna geçen bireyin kendi benliğini unutması karamsar gelecek tasarımının tablosunu göstermektedir. Laughey $(2010$, s. 118) bu noktada hemen her toplumsal yapıda, belli birey ya da kurumların tepki gösterme, düşüncesini açıkça söyleme ve diğerlerini etiketleme anlamında toplumun diğer bireylerinden daha fazla güce sahip olduğunu, belli bir durum veya sorun karşısında medya, din kurumları, siyaset mekanizmaları gibi devletin ideolojik aygıtlarının toplumsal tepkiyi şekillendirebilecek ayrıcalıklı bir konumda yer aldığına dikkat çekmektedir. Bu durum ister istemez bireyde sistemin dışına çıkmamak adına, düzene karşı gelme korkusunu yaşatmaktadır. 


\subsection{Kimliksizleșme/Yabancılașma}

İnsanoğlu yaşamı süresince var olma mücadelesi vermek ve diğerlerinden farklııı̆ını ortaya koymak üzere mutlaka bir kimliğe bağlanma ve buna göre rolünü oynama gereği hissetmektedir. Toplumların modernizmle tanışmaya başladığı günden itibaren kimlik kavramı, sosyal değişime paralel olarak değişken, çok katmanlı, devingen ve yeniliklere açık bir yapıda kendini göstermektedir. Frankfurt Okulu, Baudrillard ve diğer post modern kuramcılara göre kimlik özerk, kendini kuran özne; modern bireylerin, bir bireycilik kültürünün başarısı iken, toplumsal süreçler ve dolayımlanan ve tüketicileşen bir kitle toplumundan dolayı parçalanmakta ve ortadan kaybolmaktadır (İmançer, 2003, s. 243).Düzenin düzensizlikten doğabileceğini, genel bir bozulma, yozlaşma, yönsüzleşme ve çürümenin yansıması olarak görülebilen post modern düşüncenin (Odabaşı, 2006), toplum yapısının giderek karmaşıklaşmasına yol açarak bireyin kaybolması hissini doğurduğu söylenebilir.

Marx için yabancılaşma kavramı, bir güçsüzlük ve soyutlanmışlık duygusu olmakla beraber, insanları hem emeklerinin ürünlerinden yoksun bırakan, hem de faaliyetleri üzerinde denetim kuran ekonomik, siyasal ve sosyal düzenin yapısal bir analizi olarak ön plana çıkmaktadır. Bu noktada temel yabancılaşma düşüncesi, kapitalist ve totaliter düzen altındaki gücümüzün başkaları tarafından ele geçirilerek yabancılaştırıldığı, yaşamımız üzerindeki iktidarımızdan mahrum bırakıımamızın göz ardı edilemeyecek bir gerçeğidir (Holloway, 2008). Özellikle bu kimlik kaybının ve bireyin kaybolma hissinin artmasında şartlanmanın önüne geçmek amacıyla yaşanan gerçek dünyanın algılar dünyasına dönüştürüldüğü, bu dünyanın da 'garip' kılındığı medyanın ve iletişim teknolojilerinin önemli bir payı olduğunu vurgulamak gerekmektedir. Zaten teknolojik bir dönüşümün getirdiği distopyanın sosyal gerçekliğinde, elektronik bilgi araçları tarafından sürekli bir kargaşa ve toplumsal histeri ortaya çıkarılmaktadır. Brecht'in ünlü yabancılaştırma etkisi bireylerin olaylar, olgular ve durumlar karşısındaki bilişsel, duyuşsal ve davranışsal çerçevede gelenekselleşen alışkanlıkları tahrip etmesinin, özellikle toplumsal gerçekliği yeniden kurup değiştirme aracı olarak kullanılmasıyla aynı paralellikte gittiğini göstermektedir (Wright, 1998, s. 10).

Distopik metinlerin çoğunda totaliter rejimi korumak ve ülkenin istikrarını sürdürmeye yönelik zorlamaya başvurmadan çeşitli propaganda ve bilimsel tekniklerle insanlar kendisine yabancılaştırılmaktadır. Dolayısıyla, bu yönlendirme sürecinde toplum tarafından bir takım ritüellerin uygulanması da kaçınılmazdır. Ritüeller ile tamamen toplu bir haz (tüketim) gerçekleştirilmektedir. Esas olan alınan tepkinin kendisidir. Bu ritüellerden "marşlar" distopik metinlerde sıklıkla bahsedilen öğelerin başında gelmektedir. Distopik metinlerde totaliter yönetimin bir aracı olan marşlar, her zaman insanlara ilahi edasıyla söylettirilmek istenmektedir. Özellikle dinin inanma ihtiyacını karşılaması ve sanatın bireyi kendi özgürlüğüne kavuşturabilmesi bakımından var olamayacağı apaçıktır. Bunu engellemek için Cesur Yeni Dünya'da Yalnızlık Hizmeti ve Bin Dokuz Yüz Seksen Dört'te ise Nefret Haftası totaliter ideolojiyi besleyen önemli ritüellerdir. 


\subsection{Bireysel Özgürlüğ̈ü Kaybı}

Bugün toplum içerisinde sağlıklı ilişki kuramayan, diğer bireylerle bağlantı sağlayamayan içinde yaşadığımız kaygı çağında bireyin kendi benliğini elinden alan makinelerin payı yadsınamaz. Distopik toplumun ana göstergelerinden makinelerin, insanların kendi başına karar alma, seçim yapma mekanizmasını körelterek temel özgürlüklerini elinden alması göze çarpmaktadır. Sanayi devriminden bu yana makinelerle özdeşleşen insanlar, bu aşamanın ileri boyuta taşınmasıyla zamanın çoğunu televizyon ve bilgisayar ekranlarıyla şekillendirmesiyle post modern vatandaş portresine bürünmektedir. Bireyler başta kendilerinden olmak üzere birbirlerinden uzaklaştırılarak, mevcut sistemi ne kadar eleştirmez ve bu konuda düşünmez olursa, o kadar mutlu, özgür ve rahat olacağı bir pragmatik anlayış aşılanmaktadır. İnsanın ve toplumsal ilişkilerin araçsallaştırılan kurgusal gerçekliği ve metaya dönüşmesi; 'özgür, bilinçli ve bireyleşmiş insan olmasını zaten ortadan kaldırmış' ve insanların her biri birey olarak, diğer insanları kendisinin bir yere gelmesi veya bir şey elde edebilmesi için bireysel özgürlüğünü kaybetmiştir (Kaplan, 2006, s. 215).

Bin Dokuz Yüz Seksen Dört'te ne yapılacaksa sadece Büyük Birader'in istekleri karşılanarak Parti'nin istikrarı sağlanmaya çalışılırken, insanların kendi bilinçlerinden uzaklaştırılarak yabancılaştırılması esas alınmaktadır (Orwell, 1984). Cesur Yeni Dünya ve Bin Dokuz Yüz Seksen Dört gibi yine totaliter bir düzende bireyin, yani "ben"in yıkıldığını gösteren Biz'de, madde ve makineye uyarlanabilecek mekanikçi bir sistemin insanlar üzerinde tatbik edilmesi söz konusudur. Birleşik Devlet’te yaşayan insanlar vatandaş olarak bir adla anılmasının aksine kendilerine bir numara verilmesi, insanların boş vakitlerinin devlet tarafından dakikasına göre belirlenmesi bireysel özgürlüğün kaybının önemli göstergeleri olarak göze çarpmaktadır. Gelecekteki bir başka baskı toplumunu konu edinen Fahrenheit 451 'de ise teknolojinin önemli iki öğesi konumundaki televizyon ve otomobilin, insanların sosyal ve kültürel yaşamına etkisinden ötürü günlük hayat temposunu hızlandırdığı, bu hıza uyum sağlamak için kültürün yozlaşmasına yol açarak kendi benliğinden uzak bir davranışın yaygınlaştığı konu edinmektedir.

\section{4. Șiddetin Normalleșmesi}

Bauman'a (2011, s. 258) göre baskı, güvenli biçimde kurumsallaştırıldığı zaman, odak noktasından ayrılarak gündelik hayatın geri planına çekilip, görünmez konuma gelmekte ve monotonlaştıkça dikkat çekme gücü azalmaktadır. İşte bu noktada insanların düşüncelerini ve davranışlarını sürekli etkilemek suretiyle düzenin korunması amacıyla sosyal kontrol devreye girmektedir. Bireyin ya da toplumun bilinçli veya bilinçsiz olarak düşünce, duygu ve/veya eylemlerini değiştirme, yönlendirme, etkileme olarak tanımlaman "sosyal etki"nin kuvvetli olduğu ortamlarda sosyal kontrolün de işlemesi kaçınılmazdır (Sakallı, 2006, s. 14). Etkili bir ikna mekanizmasının yerine ikame edebilen sosyal kontrol sayesinde insanlar, özgürlüklerinden ödün vermediklerini zannederek amaca uygun bir şekilde gönüllü olarak hareket etmektedirler. Özellikle burjuva toplumsal düzenin gündelik yaşamı düzenleyen bir takım kuralların varlığı, bir 
kurumun ve/veya devletin bedenler üzerinde tasarruf hakkını elde etmesi anlamına gelir ki bu tablo da şiddetin farklı ve bir o kadar ciddi boyutunu gözler önüne sermektedir. Kurumlar aracılığıyla uygulanan şiddet için, şiddetin simgesel konuma dönüşmesi anlamında bir dönüm noktası olduğu söylenebilir.

Toplumsal denetim konusuna eleştirel bir bakış açısı kazandırmak amacıyla Bourdieu tarafından üretilen sembolik ya da simgesel şiddet, "fiziksel şiddet ya da baskının var olmadığı yerde şiddetin kibar maskesi altına girmiş gizli bir formudur” şeklinde tanımlanmaktadır (Thompson, 1984, s. 56). Orwell'in Bin Dokuz Yüz Seksen Dört adlı eserinde Barış Bakanlığı'nın savaşı yürütürken, Sevgi Bakanlığı'nın soruşturma ve işkence işleri ile uğraşması, Parti tarafından kitleleri denetim altına tutmak adına geçmişi denetim altına almak için tüm belgelerin ihtiyaca göre yeniden yazılması, cinselliğin bir tatmin yöntemi olmaktan çıkıp devlete çocuk yapma konumuna indirgenmesi ve "iki Dakikalık Nefret Duruş” ları şiddetin normalleştirildiğinin önemli göstergelerindendir.

\subsection{Mükemmelleștirme}

Elit azınlık ve vatandaşlar arasındaki iletişimin yönü bilgi amaçlı kullanılan iletişim teknolojileri sayesinde karşılıklı olsa da, bu araçları bilinçsizce kullananların hatta yönetilenlerin baskın grupların egemenliği altına girmesi kaçınılmaz hale gelmektedir. Aslında buradaki temel nokta bilgiyi bir güç nesnesi olarak kullanan işletme ve kurumların, bireyleri kendilerine hayranlığını sağlayarak üye yapmak, ürün ve hizmetlerinden yararlanmasını sağlamak ve yaptıklarıyla meşru bir zemine çekerek kendisini onaylar hale getirmektir. Distopyalarda önemli olan şey teknolojiyi kullananlar arasındaki güç ilişkilerinin sarsılmamasıdır ki bunu sağlayan temel etken Gramsci'nin "hegemonya" kavramıdır. Hegemonya bu bağlamda insanların hayatını mükemmelleştirmek için kullanılan bir araçtır. Hegemonyanın devamlılığında kurulu düzen vardır ve mükemmellik esastır. Bu mükemmelliğini ya da kusursuzluğunu kurduğu baskı ile gerçekleştirir. Reklamda ise ürünü tükettiğimiz ölçüde mükemmelliğe ulaşırız. Bu noktada düzenin devamı sağlanır. Bu sistem "kapitalizm"dir.

Çoban (2008, s.200) iletişimin ve küreselleşmenin bir bütünün iki ayrı parçası olarak hayatımızdaki yerini aldığını ve birbirini besleyerek kapitalizmin propagandasını yaptığını ifade etmektedir. Bu toplumsal dönüşümün odağında "zaman - mekân sıkışması", yerel - evrensel değerler, üretici ile tüketicinin yer değiştirebilirliği, küresel enformasyon, iletişim teknolojilerinin yayılması, hareket edebilme özgürlüğü konuları bulunmaktadır ki bunlar küreselleşmenin neden olduğu çok boyutlu değişikliğin net bir şekilde görülebileceği noktalardır (Bravo, 2010). Zaman ve mekân boyutunun ortadan kalkmasıyla birlikte sınır düşüncesi tamamen eridiğinden insanların ulaşmak istedikleri haz ve arzular daha fazla artmaktadır. Doyurulmuş bir arzu ya da istek yeni arzuların kapısını açmaya başlamaktadır. Bu küreselleşme ortamında artan çeşitlilik, bireylerin ister istemez meta bombardımanı altına girmesine sebep olmaktadır. Her türlü arzularının arkasına takılan insanlar, bilinçsiz bir şekilde karşılamaya çalışan bir tüketim toplumunu meydana getirmektedirler. 
Tüketime yönlendirilmiş toplumların özellikle ne yapmaları gerektiği konusunda aynen siyasi ve toplumsal alanda karşılaştığımız gibi ekonomik düzende de mükemmelliği yansıtan totaliter anlayışın izlerini bulmak mümkündür. Bu anlayışın altında insanların beyinlerini yönlendirme suretiyle belirli ritüeller eşliğinde, narkotik uyuşturuculardan farklı çeşitli ilaçlarla huzurlu ve sözde mutlu bir kimliğe sürüklemek yatmaktadır (Becan, 2015, s. 67).

\subsection{Sinıf Ayrımı}

İnsanlar yaşamlarında kendilerini sürekli var etme çabasını göstermek adına bir sınıfa veya gruba ait olma ihtiyacını hissetmektedir. Bu ihtiyacın temelinde bazı zamanlar ekonomik ya da politik güdüler olabildiği gibi bazı zamanlar ise toplumsal veya ideolojik güdülerin harekete geçirilmesi yatmaktadır. Bourdieu sınıf kavramını bir kimlik, eylem ve eşitsizlik şekli olarak merkeze koyarak, bir tarafı ampirik diğer tarafı analitik olmak üzere iki farklı biçimde tahlil etmektedir. Ampirik tarafıyla daha çok ekonomik sınıf düzeni (üst-orta-alt sınıf) açısından bakılırken, analitik düzlemde özellikle çok yönlü sembolik savaşların sonucunda ortaya çıkan sınıfların içindeki görünmeyen sosyal alanlara odaklanılmaktadır (Wacquant, 2013). Bourdieu temel itibariyle, bireylerin/aktörlerin çeşitli maddi ve sembolik sermaye araçları sayesinde belli bir konuma erişmek için sürekli mücadele içerisinde olduklarını belirtmektedir. Bu mücadele içerisinde aktörler, alanda ellerindeki sermaye hacmine ve farklı sermaye türlerinin (ekonomik, kültürel ve sosyal) toplamı içindeki göreli ağırlığına göre dağılmaktadırlar (Bourdieu ve Wacquant, 1992).

Bunun yanı sıra Mahalingam çeşitli sosyal gruplar arasındaki güç farklılıklarının ve kaynaklara erişme biçimlerinin bireyin sosyal sınıfı nasıl kavramsallaştırdığı üzerinde etki edebileceğini söylemektedir (Mahalingam, 2003). Bu güç farklılıklarının özellikle kişinin içinde bulunduğu sınıfla, yaşam tarzıyla ve hatta kültürel yapıyla daha fazla açıklığa kavuşması söz konusudur. Modern dönemde bu güç farklılığının en çok hissedildiği alandan bahsedildiğinde insanların tüketim biçimi akla gelmektedir. Tüketimle ilgili kararlar alınırken her sınıftan birey zaman zaman statü işaretine göre değerlendirme yapmaktadır. Tüketici aktörler, yaptıkları tüketim faaliyetleriyle sosyal sınıfa ait bir göstergeye göre hareket etmekte ve bundan da sosyal anlamda fayda sağlamaya çalışmaktadır. Bundaki en temel sebep, insanın her zaman durumunu diğerine göre daha iyi ve daha güçlü kılma arzusudur.

Distopik metinlere bakıldığında ortak bir özellik olarak katı bir sınıf anlayışı görmek mümkündür. Biz'deki savaş sonrası toplum yapısı, gündelik olarak süregeldiği medeni hayat (Tek Devlet'in kusursuz sakinleri) ve kırlık/doğa alanı (teknolojiden yararlanamayan ilkel grup) olmak üzere birbirinden izole edilerek bir duvar ile ayrıştırılmaktadır (Zamyatin, 2012). Cesur Yeni Dünya'da da buna benzer bir durum söz konusu olmakla beraber, medeniyet ile yabanıl yaşam birbirinden ayrılmaktadır. Özellikle 'Alfa', 'Beta', 'Gama', 'Epsilon' gibi Yunan harfleri şeklinde belirlenen katmanlara göre insanlar çalışma hayatına ve boş zamanlara yönelik çeşitli şartlandırma tekniklerine tabi tutulmaktadır (Huxley, 1998). Bin Dokuz Yüz Seksen 
Dört'te ise daha keskin bir yapılanmaya gidilerek insanlar, yöneticiler/parti üyeleri ve proller olarak ayrılmaktadır (Orwell, 1984).

\section{TV Reklamlarına Yönelik Bir Analiz}

Reklamlara yönelik tasarlanan araştırma sürecinde, temel itibariyle araştırma nesnesi olarak devingen görüntülü reklamlarda işlenen anlatım dilinin nasıl ve neden tercih edildiği üzerinde durulmaktadır. Devingen yapıdaki televizyon reklamlarında yerleştirilen mesajların çözümlenmesi, çalışmanın işlevsel boyutunu oluşturmaktadır. Bu bölümde araştırmanın sorunu, ne amaçla yapıldığı, nasıl bir öneme sahip olduğu aktarıırken, araştırmada hangi yöntem ve modelden yararlanıldığı ve hangi sınırlııklar çerçevesinden hareket edildiği hususunda genel bilgiler verilmektedir.

\subsection{Araștırmanın Sorunu}

Birbirinden farklı alanda faaliyet gösteren işletmeler, tasarladıkları farklı reklam kampanyalarıyla tüketicileri etkilemeye ve onların tercihlerini kazanmaya çalışmaktadırlar. Bu reklamlarda tüketicilerin ilgili ürüne/hizmete/konuya yaklaşmasının önünü açan temalar ve vaadlerin yanı sıra, aynı amaca hizmet eden distopik unsurlara rastlamak mümkündür. Farklı sektörden şirketlerin reklamlar aracılığıyla özellikle bu distopik unsurlar üzerinden tüketicilerin tercihine yön verdikleri görülmektedir. $\mathrm{Bu}$ doğrultuda reklamlar kapsamında incelenen distopik çerçeve aracılığıyla bireyin rahatsız edilmesi ve bu durumdan kurtulmanın yolu olarak reklamı yapılan ürün ve hizmetlerin gösterildiği ortaya konulmaktadır.

\subsection{Araștırmanın Amacı ve Önemi}

Bu çalışma öznenin metalaştığı, ihtiyaçların isteklere dönüştürülerek özgünlüğünün yitirildiği ve gerçekliğin yerini temsilinin aldığı içinde yaşadığımız tüketim evreninden hareket etmektedir. Çalışmanın amacı, kültürel - politiğin ana odağı haline gelen distopya olgusunun, sembolik tüketim mekanizmasının ana çarklarından biri olarak kabul edilen reklamlarda nasıl işlendiği gösterilmeye çalışılmaktadır.

Çalışmada bu temel amacı gerçekleştirebilmek için şu temel sorulara yanıt aranmaktadır:

S1 - Distopya kavramsal olarak reklamlarda nasıl desteklenmektedir?

S2 - Reklamlarda distopik çerçeve ne şekilde örneklendirilmektedir?

S3 - Reklamcılık ve distopya kavramları arasındaki ilişki nedir?

Çalışma kapsamında mutlak mutluluğa ulaşmayı çabalayan bireylerin aslında tükettiği imajlarla temeldeki huzursuzluğu geçici bir süreliğine yok edip, gerçeklikten uzaklaşmasını ve rahatlamasını temel alan distopik evrenin, reklamlar tarafından nasıl desteklendiği incelenmektedir. Hem uluslararası alanda hem de ülkemiz genelinde distopya ve reklam odağında yapılan çalışmaların oldukça yetersiz olduğu düşünüldüğünde, bu çalışmanın literatüre olan katkısı anlaşılmış olacaktır. Bu 
çalışma temel itibariyle, devingen yapıdaki televizyon reklamlarının, distopik çerçeve bağlamında çözümlenmesi ve mercek altına alınması bakımından önemli bir rol oynamaktadır.

\subsection{Araștırmanın Metodolojisi}

Distopya kavramının reklamcılık sektöründe ve reklam uygulamalarında ne ölçüde kullanıldığı, genel olarak distopya evreninin hangi felsefi ve düşünce özellikleriyle reklamlarda yansıtıldığını incelemeyi amaçlayan bu çalışmada; 'Reklamda Distopik Çerçeve' açıklanmış ve Türk televizyon reklamlarından örneklerle nitel araştırma yöntemi altında, metin analiziyle örneklendirilmiştir. McKee (2003, s. 4) metin analizini, her hangi bir görsel veya yazılı metnin yorumlanması görmektedir. Okunabilir metin olması dışında sembolik anlam ifade eden ve kültürel yorumu da içeren belge veya doküman olarak ifade edilebileceği gibi, daha da önemlisi metin analizi, kültürlere özgü ve metnin geçtiği zamana ilişkin anlamlandırma ve yorumlama yapma işi olarak tanımlanmaktadır.

Çalışmada distopya ve reklam ilişkisi, tüketim evreninin endüstrileşmiş yapılarından biri olan televizyon reklamları üzerinden incelenmiştir. Çerçeve kapsamındaki distopik unsurlara ilişkin literatür taramasının ardından, başlıkların örneklendirilmesi için gerekli televizyon reklamları derlenmiştir. Her bir televizyon reklamı birden fazla distopik unsuru örnekleyebilecek bir yapıda olmasına rağmen, tüm unsurlar için ayrı ayrı reklamlar seçilmiş ve analiz edilmiştir.

Televizyon reklamlarının Türk yapımı olmasına dikkat edilmiş ve belirli bir zaman diliminde yayınlanan reklamlar incelemeye dahil edilmiştir. 02 - 06 Nisan2018 tarihleri arasında yer alan beş günlük süreçte, 'prime time' reyting sonuçları dikkate alınmak suretiyle, programların reklam kuşağındaki spotlar not edilmiş ve tamamına YouTube internet sitesi aracılığı ile ulaşıımıştır.

Belirtilen günlerde ilgili programlar ve reklam kuşaklarında yer alan spotlar belirlenmiş, birbirinin aynısı olan ve distopik unsurlar açısından analiz edilmeye değer bulunmayan spotlar elendikten sonra, 32 adet reklam filmi Reklamcılıkta Distopik Çerçevesi açısından incelenmiştir. Çerçevede belirtilen unsurlarla birebir eşleştiği düşünülen 6 adet reklam filmi seçilmiş ve çözümlenmiştir. Araştırmanın evreni, görsel ve sözel açıdan mesaj aktarabilme noktasında distopik unsurların daha net bir şekilde elde edileceği varsayımından hareketle televizyon reklamları olarak belirlenmiş, beş günlük süreçte en fazla izlenme oranına sahip program kuşaklarında yayınlanan reklamlara ulaşılmasıyla da örneklem elde edilmiştir. Çalışma kapsamında, 6 televizyon reklamı amaçı örneklem yöntemi ile seçilmiştir. "Amaçlı örneklem, örnekleme seçilen kişi ya da objelerin araştırmacının amaçlarına en uygun yanıtı verebilecek birey ve objeler arasından seçilmesidir" (Aziz, 2008).

Çözümleme sürecinin sınırlılığı, iletişim araçları içerisinde görsellik açısından etkisi en güçlü olan ve yaygın olarak kullanılan televizyon ortamında yer verilen reklamlar 
çerçevesinde belirlenmiştir. Dolayısıyla çalışmanın ilk kısıtlarından biri televizyon mecrasında yayınlanan reklamların tercih edilmesidir. Bu araştırma sürecinde televizyon, reklam mesajını diğer mecralara oranla çok daha yaygın bir kitleye ulaştırma özelliğinden dolayı temel mecra olarak değerlendirilmektedir. Harvey (1999, s. 79), tüketim kültürünün teşvikinin televizyon bağlamında ele alınmasını, kapitalist üretimi karşılayacak tüketim taleplerinde intiyaç yaratmak adına canlılık getirici olduğundan önermektedir. Aynı zamanda ülkemizde bu alanda yapılan çalışmaların eksikliği göz önünde bulundurulursa, sadece televizyon mecrasının incelenmesinin bile tek başına reklam ve distopya literatürüne önemli bir katkı yapacağı düşünülmektedir.

\section{Reklam Spotları Analizine Yönelik Bulgular}

Toplumsal denetim sürecinin çalışmasını sağlayan mekanizmaların başında gelen reklamlar, totaliter sistemin vazgeçilmez araçlarındandır. Karşıtıklar aracılığıyla bir seçim yapma ortamı yaratarak tüketici davranışlarını yönlendiren reklamların distopik evrende nasıl şekillendiğini incelemek araştırmanın ana odağını oluşturmaktadır. Literatür kısmında ayrıntılı olarak açıklanan kuramsal bilgiler çerçevesinde, reklamın ideolojik göstergelerinin distopik çerçeveyle çakışmasından hareket ederek, reklamların bize aslında ne söylemek istendiği açığa çıkarılmak istenmiştir.

\subsection{Northgate Ankara Reklam Spotu Analizi}

Tüketim kültürü ile statüyü yükseltmenin gerçekleştirilebileceğinin anlatıldığı reklam filminde, Northgate Ankara'yı tercih edecek kişilerin kendisini cennette bulacakları vaad edilmektedir. Farklı bir yaşam tarzının sunulmasında 'doğa', 'zenginlik', 'aidiyet', 'prestij', 'tasarım'ı baz alarak mutlu bir gelecek beklentisi verilmektedir. Reklam filminde Northgate Ankara'da yaşamak karşılığında elde edecekleri ayrıcalıklı ve mutlu bir hayatın sonucunda bir iktidar alanının oluşturulması söz konusudur. Tüketim cenneti olarak ütopyavari bir şekilde sunulan Northgate Ankara'nın teknolojinin, hızın ve doğanın bir aradalığında, şıklık, lüks, kendini farklı bir sınıfta hissetme ayrıcalığı altında, yeni bir kimliğe kavuştuğunu zanneden birey, zaman içerisinde bu ayrıcalığı nesnede aramaya başlamaktadır. Sınıf ayrımını belirgin hale getirmek için bütün distopik metinlerde anlatılan alanların birbirinden farklılaştırılması sağlanmaktadır. Bu çerçevede packshotta gökyüzünden çekim sahnesiyle giren Northgate Ankara için, bilinen Ankara'dan yalıtılmış bir şekilde çevresi ormanlarla kaplı, ulaşılması zor bir ütopik ada/yok ülke görünümünde sunularak, Biz'in Tek Devlet'indeki vatandaşların yaşadıkları 'cam kafes' mitine gönderme yapmaktadır.

Ütopyanın ve kent olgusunun ortak bir tarih paydasında buluştuğunu belirten Harvey (2008, s. 192), her ütopyanın mimari/kentsel bir yapıya sahip olduğunu ve toplumsal nitelikleriyle şekillendirilmiş, bir tüketim mekanizması içinde geliştiğini ifade etmektedir. Kapitalist sistemin sürekliliğini sağlamak için sunulan bu tip yerleşim tarzları, toplumsal farklıııkları ve ayrışmayı pekiştiren, kendisinden olmayanı kabul etmeyen bir yapılanmaya götürmektedir. Yeni yerleşim alanlarının temel özelliği güvenliği olmayan, yaşanmaz, keşmekeş bir kent karşıtlığı içinde ayrı bir bölgede kendini izole etmesidir. 
Böylece insanların birlikte hareket etme olanağı ortadan kalkmakta, sosyal aidiyet, dayanışma ve yardımlaşma gibi duyguların yitimiyle sonuçlanmaktadır. Dolayısıyla distopyada kurallara uyan bireyler, düzenin bir parçası olmaya mahkûm kalmaktadır.

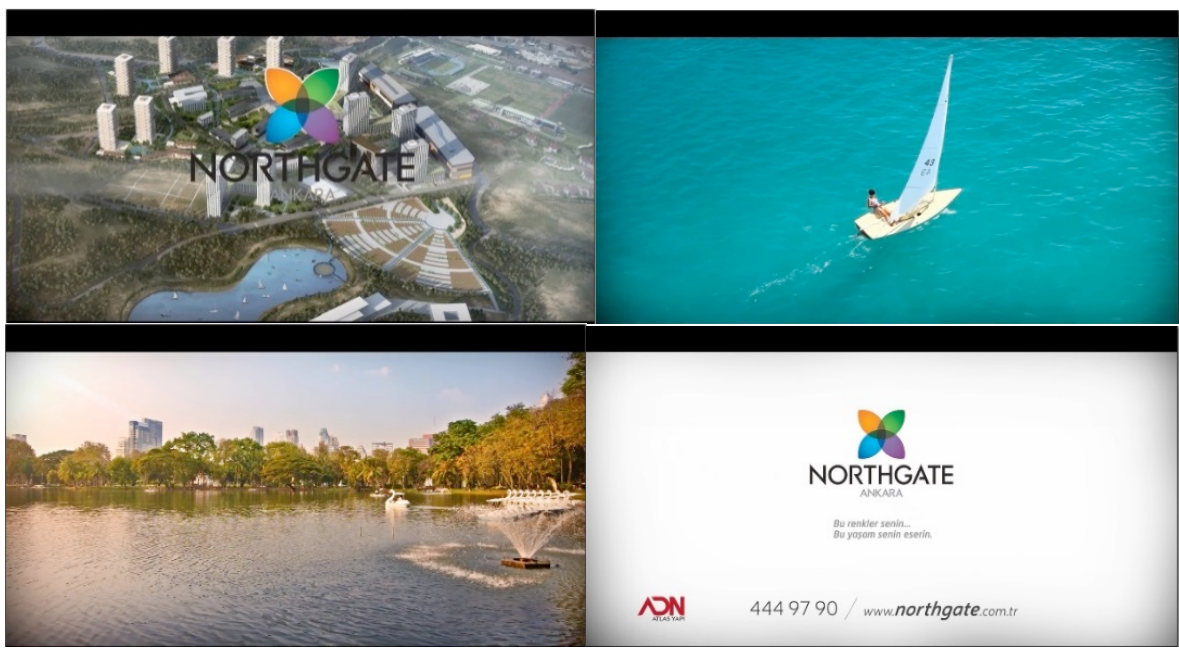

Şekil 1. Northgate Ankara Reklam Spotundan Kareler - "Sınıf ayrımı"

\subsection{Veet Reklam Spotu Analizi}

Reklamdaki metinde, bayanların genellikle ciltlerindeki veya bedenindeki istenmeyen görüntü sorunuyla ya da olumsuzluklarla karşı karşıya kaldıklarında verdikleri tepki ön plana çıkarılmaktadır. Reklamdaki genç bayan, zamanında yaşadığı tüylenme sorununun kendisinin, çevresindeki insanlara özgüvenle yaklaşamamasına sebep olduğunu düşünmektedir. Bu olumsuz durumdan kurtulmak için genç kadın, Veet tüy dökücü kremine başvurmakta ve istediği sonucu yaşadığı deneyimle aldığı anlatılmaktadır. Dolayısıyla zaman içerisinde insanın fiziksel yapısında oluşan olumsuzluklar ve bu olumsuzlukların, bireyin bulunduğu çevredeki diğer insanlarla girdiği sosyal ilişkilerinde getireceği sıkıntılar yansıtılmaktadır. Kültür endüstrisinin bir parçası olan reklama, kapitalizmin çıkarını destekleyecek şekilde biyo-politik sürecin devamını sağlayan bir mekanizma olarak bakııması söz konusudur. Beden üzerinde oluşturulan gerçekliklerin bilimle gerekçelendirilmesinin bir örneğine Veet reklamında karşılaşmak mümkündür. Foucault (2003, s. 103) kapitalizmin biyo-iktidar normlara uymak üzere insanların davranışlarını biçimlendirerek güçlendiğini, toplumun insanlar üzerindeki kontrolünün sadece bilinç ve inanışlar yoluyla değil, bedenle ve beden üzerinden de sağlandığını açıklamaktadır.

Temelde sorun-çözüm şeklinde, temel bir karşıtlık içinde kurulan Veet tüy dökücü krem reklamında, tüylenme problemiyle çevrelenmiş olarak gösterilirken, çözümü Veet kreminin kullanımasıdır. İnsanın sorumluluk odağına yerleştirilen beden, toplumsal prestij öğesine dönüştürülebilen bir araç olarak ele alınmaktadır. Temel anlamsal boyutta bedenine sahip çıkamazsan ve iyi bakamazsan, toplumsal 
prestijini de kaybetmeye mahkûm olursun tehdidi verilmektedir. Reklamda bireyin ürünü tükettiği ölçüde mükemmel bir cilde ulaşabileceği ve böylece kendisindeki eksikliği tamamlayabileceği, düzenin bir parçası haline geleceği dikte edilmektedir. $\mathrm{Bu}$ kurulu düzen (kapitalizm) mükemmelliğini, bedenine sahip olma baskısıyla gerçekleştirmektedir. Ürün kullanıldığı sürece düzenin devamı sağlanır. Düzenin dışına çıkmamak adına, bireyin/tüketicinin reklamdaki kadın karakter gibi bakımlı bir cilde sahip olup olmadığı yönünde kaygısını açığa çıkarmak ve bu tehdidi azaltmak için eyleme geçmesini sağlamak amaçlanmaktadır. Reklamda bu çabanın sonunda bakımlı bir cilde sahip olmama ve beğenilmeme korkusunu yenmenin tek çözümünün Veet almaktan geçtiği vurgulanmaktadır. Buradan serbest piyasa ekonomisinde özgür olarak nitelendirilen tüketiciye, organik bütünlüğünü bozmamak ve sürekli izlenmemin verdiği baskı üzerine seçim hakkı tanınmaması sonucuna ulaşılmaktadır.

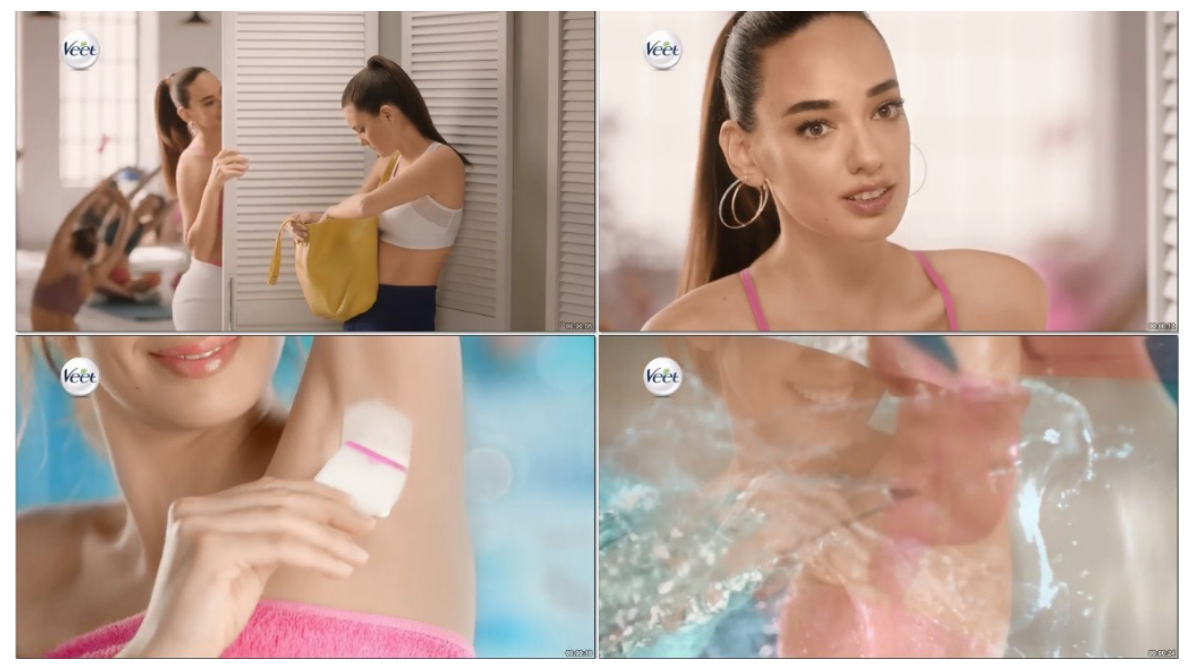

Şekil 2. Veet Reklam Spotundan Kareler - "Korku"

\subsection{Atasay Reklam Spotun Analizi}

Atasay'ın "tak sana yakışanı" konseptine sahip reklam filminde, çok çeşitli yaşlardan farklı karakterlere, bambaşka mekânlardan çok farklı stillere sahip kadınlar yer almaktadır. Bu kadınların ortak özelliği ise Atasay takılara sahip, özgüvenli, kendi tercihlerini yapan güçlü kadınlar olmak istemeleridir. Reklam filmi boyunca söylenen rap şarkısı, günlük hayatta fiziksel, duygusal, çevresel nedenlerle pek çok şeyi kafasına takan kadınları işaret etmektedir. Kadınlara her şeyi kafaya takmamalarını söyleyen reklam filmi, tek bir kadın prototipi olmadığını, her kadının özel olduğunu anlatmaktadır. Atasay bu yeni duruşuyla "Tak sana yakışanı!" diyerek kadınlara sahip oldukları gücü hatırlatmakta ve kişiliklerini yansıtmaları için yepyeni deneyim fırsatı sunmaktadır. Arzu nesnesi olarak ön plana çıkan Atasay, hayatında özgürlüğüne ve mutluluğuna kavuşmak isteyen bireyler için ürünü/nesneyi kullanmak üzerinden büyülü bir tüketim evrenine kapı aralamaktadır. Bu tüketim evreninde Atasay, kadını 
mutlu etmekle kalmaz, yaşamak istediği rahat bir hayatı da sunmaktadır. Atasay reklamının kadın karakterleri salonda bir süre yürüdükten sonra karşısına çıkan aynaya baktığında, 'sıkıntılar ve baskılar içinde yaşadığını fark eden' ego ile 'kendisini yeniden keşfedilmeyi bekleyen' ideal benlik arasında ego-ideal çatışmasını yaşamaktadır. Önce ürüne değerini veren tüketici, doyurulmamış bilinçaltı arzuları ürünle satın alarak tekrar bu değeri elde etmekle, simgesel değeri kendisine mal eden ürün sayesinde insanın kendisine yabancılaşmasının önü açılmış olmaktadır.

Burada aslında, bireyin/tüketicinin reklamdaki kadın karakter gibi özgürlüğüne kavuşup kavuşamayacağı yönünde kaygısını açığa çıkarmak ve bu endişesini azaltmak için eyleme geçmesini sağlamak amaçlanmaktadır. Tüketicinin ürüne ihtiyacı olmadığı halde reklamdaki kadın gibi kendi hayatını farklı bir şekilde kurgulamak için yapay isteklerin yaratılması kendisine yabancılaştırılması görüşüne işaret etmektedir. Yabancılaştırmayı daha da körükleyen nokta, başkaları tarafından sürekli izlendiği endişesinden mükemmel bir kadın karakterine ulaşma çabasıdır. Reklamda bu çabanın sonunda kıskanılmama, istenilir olmama ve fark edilmeme korkusunu yenmenin tek çözümü olarak parfümü almaktan geçtiği anlatılmaktadır. Başkaları tarafından kalıplara sokulmanın ve yapay bir hayatın simgesi olan takılardan arınıp, kendisini mutlu edeceğini ve rahat hareket edeceğini düşündüğü yeni bir evrene geçerek aslında kurulu düzenin devamlıığının sağlandığı gerçeği açığa çıkmaktadır.

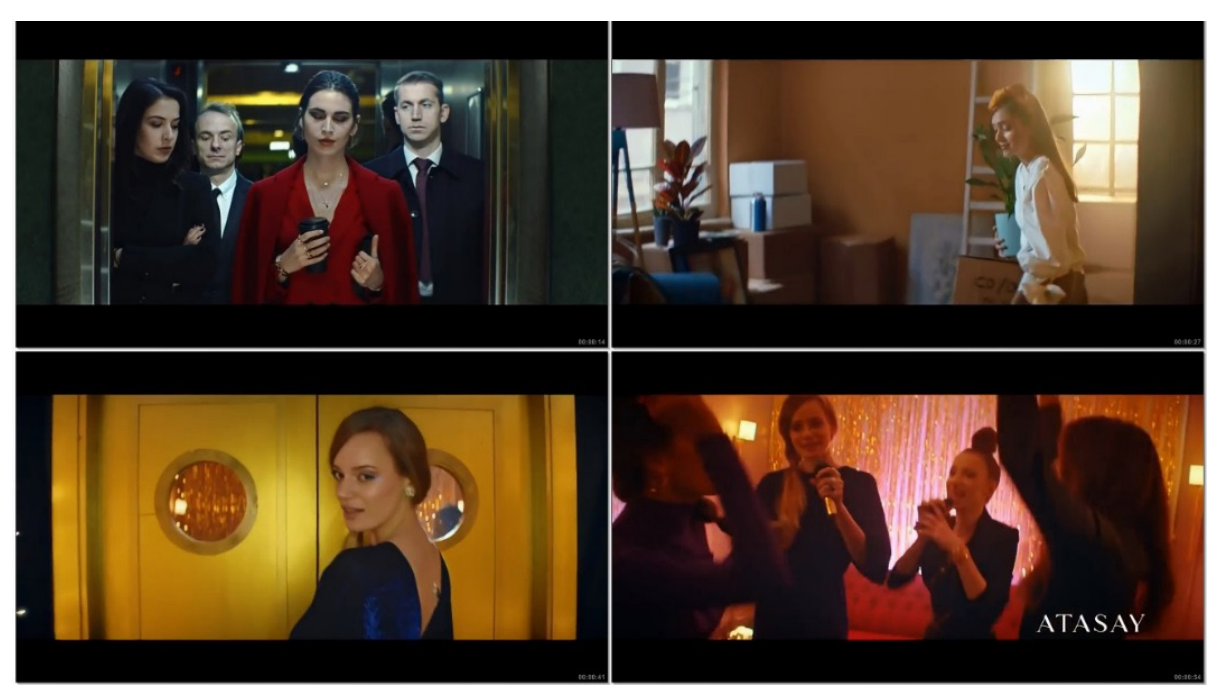

Şekil 3. Atasay Reklam Spotundan Kareler - "Yabancılaşma-Kimliksizleşme"

\subsection{Samsung Reklam Spotu Analizi}

Samsung reklamında, spor ve sanat alanında yarışmalara katılan ve dünya çapında başarı elde eden 5 Türk gencin ilham veren başarı hikâyeleri anlatılmaktadır. Samsung 
Galaxy S7 Edge'in tanıtıldığı kampanyada gençlere istedikleri her şeyi başarmanın mümkün olduğu mesajı verilmektedir. Alanında başarılı gençlerin hiçbir engel tanımadan yolları aşarak ileriye doğru gitmesi düz anlamı iken, 'güvenlik', 'ciddiyet', 'sağlamlık', 'başarı', 'mükemmellik' bütün reklamın yan anlamıdır. Reklam metni bir bütün olarak değerlendirildiğinde, hem ürünün/nesnenin tanıtıldığı hem de ürünün çevresinde bir imaj oluşturulduğu görülmektedir. Bu imaj, görsel metnin yan anlamı olarak okunabildiği gibi, görsel metinde teknoloji ve doğa ikileminin vurgulandığı göze çarpmaktadır. Kişinin kendisini başarılı bir insan figürüne ulaştırmak için Samsung kullanılması gerekliliğinin yansıtıldığı reklamda bireyi yine, nesneyi/ürünü kullandırmak yönünde güdüleyici bir tüketime teşvik ettiği anlaşılmaktadır. Kariyerinde daha yüksek bir seviyeye ulaşmayı, en iyisine sahip olmayı hedefleyen insanlar, alanında başarılı olmuş kişiler ile reklamlarda tercih ettiği ürünler/nesneler arasında ilişki kurmakta ve bu ürünü kullanıp onların statüsüne ulaşacaklarını düşünmektedir. Hayallerindeki konuma gelmeleri için bir fırsat olduğunu düşünen insanlar bu özdeşleştirme çabasına girerek kendi kimliklerini kaybetmeye mahkûm olmaktadırlar. Reklamda geçen 'Yaparsın' tümcesiyle, insanlara Samsung kullanılmasının sonucunda etrafına göre, başarılı gençler gibi her türlü engelleri aşan, sağlam ve güçlü bir kişi olacağı düşüncesi yüklenerek daha mükemmel bir hayat yaşama arzusu uyandırılmaktadır.

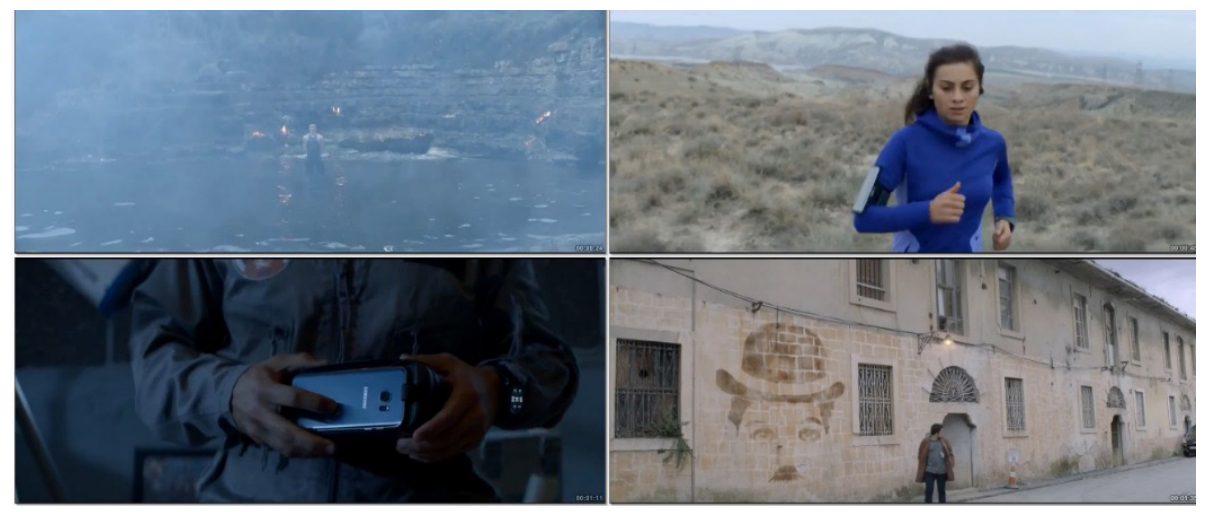

Şekil 4. Samsung Reklam Spotundan Kareler- "Mükemmelleştirme"

\subsection{Profilo Reklam Spotu Analizi}

Reklamda bir adamın eşine yanlış bir zamanda Profilo marka et kıyma makinesi alması ve bunun karşılığında eşinin mizahi bir üslupta verdiği tepki işlenmektedir. Tüketim nesnesi olarak küçük ev aleti üzerinden teknolojik hâkimiyete ve özgürlüğe ulaşmanın bir yolu olarak gösterildiği reklamda, sisteme katılmak için Profilo ev aletlerini satın almaktan başka çare yoktur. Bireyin arzuladığı yüksek performans için Profilo'dan bir parça bulması, tüketim ideolojisinin yeniden üretilmesini sağlayan ve post modern dokuyu güçlendiren bireysellik söylemini kuvvetlendirmektedir. Kadının popüler kültürdeki temsilini inceleyen feminist akademisyen Angela McRobbie (2004, s. 101)'ye göre, kadınlara "ideal" olanı betimleyen toplumsal cinsiyet normlarının dayatılması ve bunun kadınları güçlendiriyormuşçasına gerçekleştirilmesi, şiddetin 
simgesel boyutlarının etkin olmasına yol açmaktadır. Profilo reklamı, kadına yönelik uygulanan simgesel şiddetin görünmez boyutlarıyla oldukça önemli bir söylem inşa etmektedir. Reklamdaki kadını ötekileştiren söylemde en başta dikkat çeken olgu, mutfak işinin doğrudan kadın ile ilişkilendirilmesidir. Reklamın ilk kısmında kadının mutlak olarak nesneleştirilmesi söylemi, ikinci kısma geçildiğinde yerini simgesel şiddetin etkin hale geldiği bir özneleşme durumuna bırakmaktadır. Toplumsal cinsiyet rolü gereği mutfak sorumluluğu kendisine dayatılan kadın, gündelik hayatını bu sorumluluk üzerine organize etmekte ve adeta makineleşerek insanlığını yitirmeye mahkûm bırakılmaktadır. Ancak reklam söylemine göre bu durum bir yabancılaşma yerine, kadının oldukça keyifli bir biçimde gerçekleştirdiği bir eylemdir. Kadın karakter dayatılan bu hegemonya karşısında karşı bir adım olarak eşine aldığı hediyeyi kıyma makinesinden geçirip kahkahalar atarak kendi üzerinde gösterilen şiddeti açığa çıkarmaktadır. Değerli saati et kıyma makinesinden geçirmesi ve bu süreçte gayet rahat bir tavırla kahkaha atması şiddetin normalleştirildiğini göstermektedir.

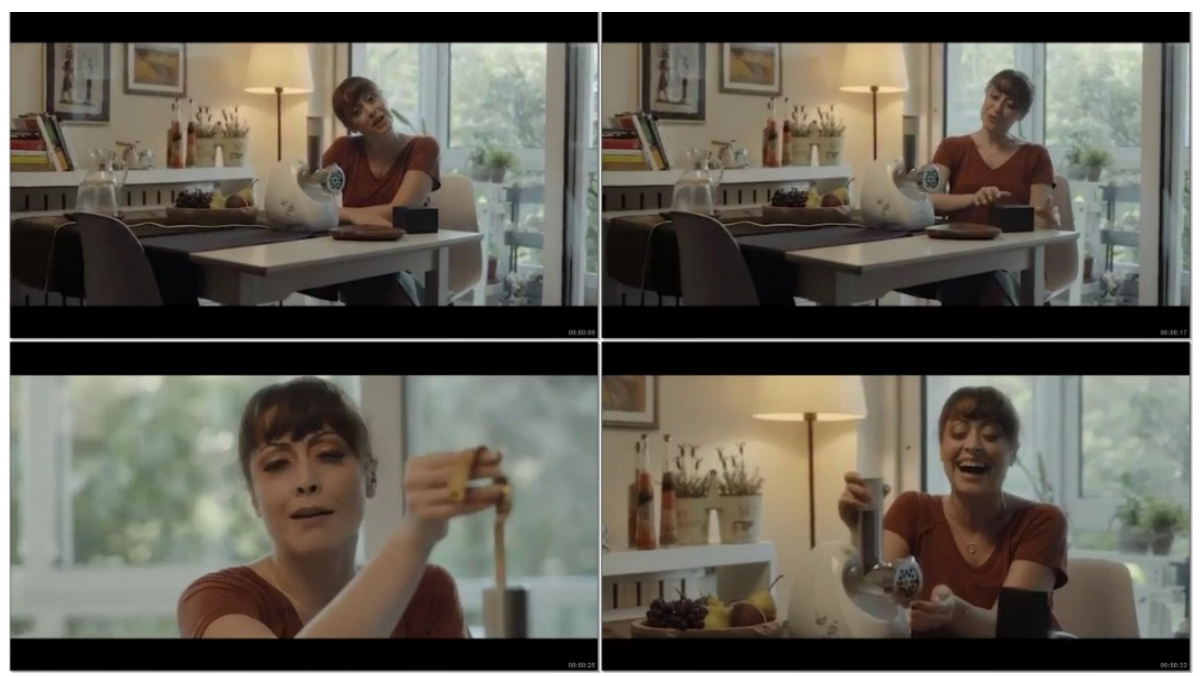

Şekil 5. Profilo Reklam Spotundan Kareler - "Şiddetin Normalleşmesi"

\subsection{Dacia Duster Reklam Spotu Analizi}

Otomobil nesnesi temelde sahip olduğu gücü işaret etmek için sosyal anlamda belirleyici bir faktördür. Bir yandan otomobilin içinin fallusla eşitlendiği, geleneksel, güçlü ve koruyucu erkek mitiyle, bu ürün için modern ve duyarlı erkek mitine aynı anda gönderme yapılmaktadır. Bir başka husus ise reklamda bir nesne üzerinden doğayla olan savaş anlatılmaktadır. Williamson (2001, s. 112) bu konuda ürünlerin, hem doğal dünyayı tahribata uğratan hem de doğal gereksinimleri bozan, fakat kendi çalışmalarını doğal ve normal olarak göstermeye çalışan bir toplumun çatışmasını somutlaştırarak hem doğayı hem de anti doğayı işaret ettiğini vurgulamaktadır. Reklamda teknoloji nesnesi olan bir otomobil, farklı mekânlardan görüntüler verilen doğal bir alanın içinde karşısına çıkabilecek tehlikeleri, riskleri savabilen ve her şekilde güvenliği, konforu 
sağlayabilen yalıtılmışlık göndergesi üzerine oturtulmaktadır. 'Hakkını ver' çengel tümcesindeki ifadeden yola çıkarak, teknolojinin gücünün doğayı düzenleyebileceği ve üründeki dayanıklılık anlaşılmaktadır.

Bir otomobilin arzu nesnesine dönüştürüldüğü Dacia Duster reklamında, artık gerçek duyguların unutturulup, yerini yapay duyguların almasıyla distopik gerçeklik kendisini yine açık bir şekilde göstermektedir. Bir insanın sevdiği başka bir insanla veya çok yakın bir arkadaşıyla doğadaki eylemlerin tadını çıkarması beklenirken, bir otomobile bağlanma eylemi tüketim toplumunun temel niteliklerinden meta fetişizminin açığa çıktığını işaret etmektedir. Böylece şu anda otomobil isteyen tüketicilerin, Dacia Duster'ı tercih etmesiyle insanların gerçek yol arkadaşını bulduklarına dair düşünmelerini sağlayarak, günlük hazları pekiştireceğine dair bir anlam üretilmektedir. Bu günlük hazlar ise tüketicilerin aldıkları Dacia model otomobili bir süre sonra üst modeliyle değiştirerek sistemin devamlılığını korumalarına ve düzenin bir parçası haline gelmelerine neden olmaktadır. Erkek karakterin Van'da otlu peynir yemesinden, nehirdeki inci kefallerin atlayışını seyretmesine kadar Dacia Duster'dan bir parça bulması, tüketim ideolojisinin yeniden üretilmesini sağlayan bireysellik söylemini ortaya çıkarmaktadır. Dacia reklamında otomobilin bir güç simgesi olması ve tüketicilerin başkaları tarafından farklı görülmesi, hayranlıkla bakılması ve kendi benliğini tekrar üretmesi uğruna bu sözde güce ulaşmak adına otomobili satın alma eylemi üzerinden bireysel özgürlüğü elinden almaya mahkûm etmektedir.

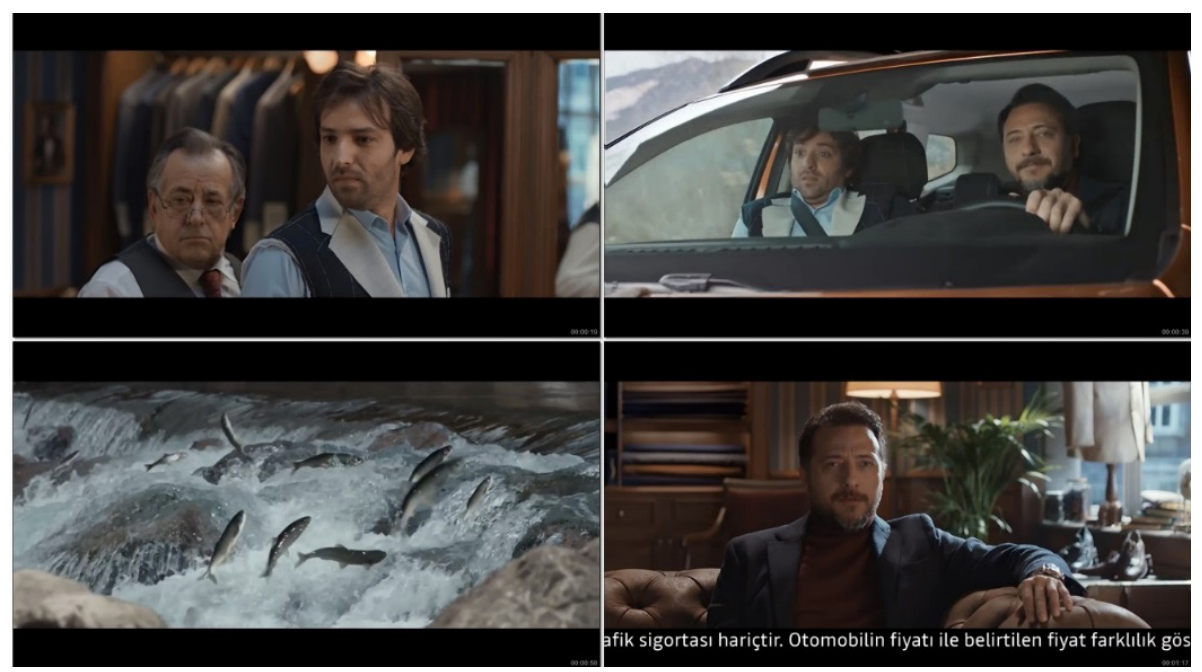

Şekil 6. Dacia Duster Reklam Spotundan Kareler- "Bireysel Özgürlüğün Kaybı"

\section{Sonuç ve Öneriler}

Günümüzde bireyleri bilinçdışı yoluyla zihinsel, duygusal ve/veya davranışsal yönde değiştirmek veya yönlendirmek için uğraşan kapitalizmin kültürel manifestosu haline gelen reklam endüstrisi, çağı takip eden değişen formlarıyla kurgusal bir hayat 
çizmektedir. Bu kurgusal hayatın içine çekilen bireyler, kendilerini yetersiz görmeleri ve huzursuz olmaları konusunda ikna edilmeye çalışılmaktadır.

$\mathrm{Bu}$ noktadan hareketle günümüzde reklamların, bilgi vermek kadar arzu ve istek yaratmak üzerine yapılandırıldığı söylenebilir. Modern yaşam biçiminin sergilendiği reklamlar, aşıladığı tüketimcilik ile doğal intiyaçların karşılanmasının yanında öznel arzuların bir bütünlüğü haline de gelmiştir. İçinde yaşanılan imajlar dünyasında zorunlu gereksinimler, reklamların da etkisiyle bireysel zevklere dönüşmüş ve tüketiciler de yeni bir kimliğe bürünmüştür. İnsanlar sonuç itibariyle kendilerini satın aldıkları metalarla/ ürünlerle tanımlamakta ve kendilerini başkalarına otomobilleriyle, katlı evleriyle ya da giysileriyle sembolik anlamlar yoluyla anlatmaktadır.

Bu çalışmada, distopyayı ele alan kaynaklardan hareketle 'Reklamda Distopik Çerçeve' farklı yönleriyle tanıtılmış ve televizyon reklamlarından seçilen örneklere uygulanmıştır. Her bir televizyon reklamı birden fazla distopik unsuru örnekleyebilecek bir yapıda olmasına rağmen, tüm unsurlar için ayrı ayrı reklamlar seçilmiş ve analiz edilmiştir. Reklamlar analiz edilirken, reklam çağrışımları ve mesajlar göz önüne alınarak niteliksel olarak distopik unsurların farklı yorumları belirlenmeye çalışıımıştır. $\mathrm{Bu}$ noktada, çalışmanın sonuçlarının diğer mecralar ve araştırmalar kapsamında genellenemeyeceğini belirtmek yerinde olacaktır.

Araştırmanın sonuçlarına bakıldığında distopik metinlerdeki izleklerin örneklem alanındaki televizyon reklamlarının görsel dilin unsurlarıyla örtüştüğünün ortaya konulması açısından önemli bir bilgi elde edilmiştir. Reklamların görsel dilin izleğinde distopik ideolojinin korku, şiddet, sınıf ayrımı, yabancılaşma, özgürlüğün kaybı, mükemmelleştirme unsurlarının işlendiği görülmektedir.

Çalışmada ele alınan televizyon reklamlarının, dışlanma korkusu, bireysel özgürlüğün yitimi, yabancılaştırma, sınıf ayrımı, geleceğe yönelik endişe ve belirsizlik gibi distopik unsurları beslemesiyle distopik evrenin üretilmesinde rol oynadığı saptanmıştır. Çoğunlukla reklamların, kitleleri, ulaşılması arzu edilen, kusursuz bir tasarı sunarak etkilemesi beklenirken bunun tam tersi işlenerek; diğer bir deyişle insanlara arzulanmayan, yaşanması istenmeyen bir tasarı sunarak da insanların etkilenebileceği ortaya konmaktadır.

Bunun en somut tarafı olarak Northgate Ankara reklam spotunda, sosyal ilişkiler gerçekliğinden yola çıkarak tüketiciye yepyeni bir dünya vaadi uğruna bireysel özgürlüğün daha yüksek statüye ulaşarak elde edebileceği telkin edilip takdir edilmeme korkusu sunulurken, Veet reklam spotunda ise ürün, sürekli izlenmenin verdiği baskı üzerine beğenilmeme, bakımlı bir vücuda sahip olmama korkusunun tek çözümü olarak gösterilmektedir. Karşı cinsleri tarafından sürekli izlendiği endişesini yaşayan kadınların toplum tarafından beğenilen, başarılı kadın profiline ulaşma çabasının anlatıldığı Atasay reklamında, yine beğenilmeme ve fark edilmeme korkusunu yenmenin tek çözümü olarak Atasay almaktan geçtiği vurgulanmaktadır. Bu açıdan tüketicinin dışlanmamak, daha fazla statü edinmek, yaşam standardını yükseltmek üzere sisteme dahil olması telkin edilmektedir. Bunun temel sebebi ise insanların 
zihnine istedikleri güce ve statüye ulaşamama korkusunun aşılanmasıdır.

Elde edilen bir diğer sonuç, televizyon reklamlarının özgürlüğün yitimine yani bireysel özgürlüğüm kaybını açığa çıkarmasıdır. Bunun anlamı ise günlük hayatın ve işlerin getirdiği stresten arınmak isteyen modern yaşamın insanların geçici de olsa kendi özgürlüklerine ulaştırmayı vaad eden reklam iletilerinin kölesi konumuna gelerek, onların isteklerini gerçekleştirmenin sonucunda yaşanan hapsolunmuşluk işlenmektedir.

İlgili literatür incelemesi sonucunda distopya evrenine ilişkin düşünce özellikleri, reklamcılıkta distopik unsurlar tarafından desteklendiği görülmektedir. Buradan hareketle analiz edilen reklamların mükemmel ve ulaşılamaz bir dünya tasarımı altında; arzu edilmeyen, tedirgin edici bir olay örüntüsü ile hedef kitleye sunulduğu anlaşılmaktadır. Reklamlarda ürüne/hizmete dikkat çekmek veya ürünü/hizmeti benimsetmek için korku unsurundan yararlanılmaktadır. Distopik unsurlar ile hazırlanan reklamlarda reklamı yapılan ürün, tüketici birey için bir tür kurtarıcı olarak konumlandırımaktadır.

Çalışma kapsamında literatür olarak yararlanılan Bin Dokuz Yüz Seksen Dört, Cesur Yeni Dünya, Biz ve Fahrenheit 451 gibi romanlardaki distopyanın sosyal gerçekliğinin, çalışmada belirlenen distopik çerçevenin unsurları ile bire bir denklik ilişkisi içinde olduğu ve araştırmada analiz edilen televizyon reklamlarının anlatım düzlemindeki kodlarla uygunluğu tespit edilmiştir.

Distopik evrenin sosyal gerçekliğine, kuramsal açıdan yapılan okumalar sayesinde inilerek oluşturulan bu çalışmada elde edilen veriler, daha önceden belirtilen araştırma sorularına ışık tutmaktadır. Bu çalışmada, distopyayı ele alan kaynaklardan hareketle 'Distopik Çerçeve' reklamlar özelinde çeşitli yönleriyle irdelenmiş ve örnekler üzerinden açıklanmıştır. Reklamlar analiz edilirken, reklam çağrışımları ve mesajlar göz önüne alınarak niteliksel olarak distopik unsurların farklı yorumları belirlenmeye çalışılmıştır. Bu noktada, çalışmanın sonuçlarının diğer mecralar ve araştırmalar kapsamında genellenemeyeceğini belirtmek yerinde olacaktır. Daha kesin sonuçlar için diğer mecralarla karşılaştırmalı içerik analizinin veya deneysel tasarım yapılıp, sonuçların istatistiksel olarak yorumlanması gelecekteki çalışmalara uyarlanması önerilmektedir.

\section{Kaynakça}

Aziz, A. (2008). Sosyal Bilimlerde Araştırma Yöntemleri ve Teknikleri. Ankara: Nobel.

Bauman, Z. (2011). Bireyselleşmiş Toplum (2. Baskı). (Y. Alogan, Çev.). İstanbul: Ayrıntı.

Becan, C. (2015). Reklamı Ters Yüz Etmek: Korku Politikası Üzerinden Anti Ütopik Bir Bakış. Konya: Eğitim.

Berger, J. (2007). Görme Biçimleri (13. Baskı). (Y. Salman, Çev.). İstanbul: Metis.

Bezel, N. (1984). Yeryüzü Cennetlerinin Sonu: Ters Ütopyalar. İstanbul: Say. 
Bouet, E. (2010). Memory Erased: Effective Thought Control in Dystopia. A. W. Ruch ve E. Kirkland (Der.), Posthumanity: Merger and Embodiment içinde (s. 35 - 45). Oxford, United Kingdom: Interdisciplinary Press.

Bravo, I. B. (2010). Küreselleşme ve Görünümleri Üzerine. Felsefe ve Sosyal Bilimler Dergisi, 10, 1 - 23. Erişim Adresi: www.flsfdergisi.com, Erişim tarihi: 12.09.2018.

Budakov, V. (2010). Dystopia: An Earlier Eighteenth Century Use. Notes and Queries, 57(1), 86 - 88, doi:10.1093/notesj/g,p235.

Çoban, S. (2008). Iletişim, Küreselleşme, Kültürel Emperyalizm ve Televizyon. C. Bilgili ve N. Tan Akbulut (Der.), Küreselleştirme Makinesi: Medya içinde (s. 189 - 211). İstanbul: Beta.

Darvish, B. ve Najjar, M. G. (2011). From Utopian Dream to Dystopian Reality: George Orwell's Animal Farm a Case Study. American Journal of Scientific Research, 18, 100 - 106.

Dima-Laza, S. R. (2012). Utopia or Dystopia: A Perfect Environment for a Perfect Existence. International Conference on Humanity, History and Society, 34, 12 - 16. Erişim adresi: http:// www.ipedr.com/vol34/003-ICHHS2012-H00005.pdf, Erişim tarihi: 20.10.2018.

Feenberg, A. (1995). Alternative Modernity: The Technical Turn in Philosophy and Social Theory. California: University of California.

Foucault, M. (2003). Cinselliğin Tarihi (H. U. Tanrı̈ver, Çev.). İstanbul: Ayrıntı.

Holloway, J. (2008). Yabancılaşma Üzerine Bir Not (D. Koptekin ve i. Kabran, Çev.). Eleştirel Psikoloji Bülteni, Erişim adresi: http://www.elestirelpsikoloji.org/arsiv/01/holloway.html, Erişim tarihi: 27.05.2018.

Harvey, D. (1999). Postmodernliğin Durumu (S. Savran, Çev.). İstanbul: Metis.

Harvey, D. (2008). Umut Mekânları (Z. Gambetti, Çev.). İstanbul: Metis.

Huxley, A. (1998). Brave New World. New York: Harper Perennial.

İmançer, D. (2003). Çağdaş Kimliğin Yapılanma Süreci ve Televizyon. Doğu-Batı Düşünce Dergisi, 6(23), 237 - 257.

Jameson, F. (2009). Ütopya Denen Arzu (B. Aydar, Çev.). İstanbul: Metis.

Kaplan, A. B. (2006). Kimliğin İfşasında Göstergenin Başat Söylemi: İletişim Kuralları Açısından Modern İnsanın Kendini Tanımlamasında ("Kimlik" ve "Kimliksizleşmesi”) Kimliğin Göstergeye Dönüştürülerek Fetişleştirilmesi Olgusuna Eleştirel Bir Yaklaşım. C. Bilgili (Der.), Medyada Olmayanlar içinde (s. 193 - 237). İstanbul: Beta.

Kellner, D. (2001). Popüler Kültür ve Postmodern Kimliklerin İnşası. Doğu-Batı Düşünce Dergisi, $4(15), 187-219$.

Kumar, K. (2006). Modern Zamanlarda Ütopya ve Karşı Ütopya (A. Galip, Çev.). İstanbul: Kalkedon.

Laughey, D. (2010). Medya Çalışmaları: Teoriler ve Yaklaşımlar. (A. Toprak, Çev.). İstanbul: Kalkedon.

Mahalingam, R. (2003). Essentialism, Culture and Power: Representations of Social Class. 
Journal of Social Issues, 59(4), 733 - 749, doi:10.1046/j. 0022-4537.2003.00087.x.

Marcuse, H. (1970). One Dimensional Man: Studies in the Ideology of Advanced Industrial Society. Boston: Beacon.

McKee, A. (2003). Textual Analysis: A Beginner's Guide. London: Sage.

McRobbie, A. (2004). Notes on 'What Not to Wear' and Post-feminist Symbolic Violence. L. Adkins ve B. Skeggs (Der.), Feminism after Bourdieu içinde (s. 99 - 109). Oxford, United Kingdom: Blackwell/The Sociological Review.

Meral, P. S. (2008). Küreselleşme ya da Emperyalizm: Değişen Gündelik Hayatın Reklamlardaki Yeni Yüzü. C. Bilgili ve N. T. Akbulut (Der.), Küreselleştirme Makinesi: Medya içinde (s. 173 189). İstanbul: Beta.

Odabaşı, Y. (2006). Tüketim Kültürü. İstanbul: Sistem.

Orwell, G. (2010). 1984. (N. Akgören, Çev.). İstanbul: Yağmur.

Öztürk, F. (2006). Ütopya ve Eğitim. Ankara: Nobel.

Riot-Sarcey, M.; Bouchet, T. ve Picon, A. (2003). Ütopyalar Sözlüğü (T. Ilgaz, Çev.). İstanbul: Sel.

Sakallı, N. (2006). Sosyal Etkiler: Kim Kimi Nasıl Etkiler? (2. Baskı). Ankara: İmge.

Shankar, A. ve Fitchett, J. A. (2002). Having, Being and Consumption. Journal of Marketing Management, 18(5-6), 501 - 516, doi:10.1362/0267257022683721.

Sucu, İ. (2011). Gözetim Toplumunun Karşı Ütopya Yüzü: Iktidar Güçleri ve Ötekiler. Atatürk Üniversitesi Illetişim Dergisi, 1(2), 125 - 140.

Thompson, J. B. (1984). Studies in the Theory of Ideology. Los Angeles: University of California.

Wacquant, L. (2013). Symbolic Power and Group Making: On Pierre Bourdieu's Reframing of Class. Journal of Classical Sociology, 13(2), 274 - 291. Doi:10.1177/1468795X12468737.

Wernick, A. (1996). Promosyon Kültürü: Reklam, Ideoloji ve Sembolik Anlatım. (O. Ahınbay, Çev.). Ankara: Bilim ve Sanat.

Wilkinson, R. (2010). Teaching Dystopian Literature to a Consumer Class. English Journal, 99(3), $22-26$.

Williamson, J. (2001). Reklamların Dili: Reklamlarda Anlam ve Ideoloji (A. Fethi, Çev.). Ankara: Ütopya.

Wright, E. (1998). Postmodern Brecht (A. Bahcıvan, Çev.). Ankara: Dost.

Zamyatin, Y. (2012). Biz(2. Baskı) (F. Arıkan ve S. Arıkan, Çev.). İstanbul: İthaki. 